\title{
Preliminary long-term predictive modelling of groundwater resources in view of climate change - a case study from eastern Poland
}

\author{
Robert DUDA ${ }^{1, *}$ and Justyna STANEK ${ }^{1}$
}

1 AGH University of Science and Technology, Faculty of Geology, Geophysics and Environmental Protection, al. A. Mickiewicza 30, 30-059 Kraków, Poland

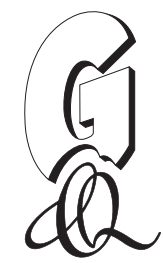

Duda, R., Stanek, J., 2019. Preliminary long-term predictive modelling of groundwater resources in view of climate changea case study from eastern Poland. Geological Quarterly, 63 (4): 643-656, doi: 10.7306/gq.1495

Associate Editor: Tatjana Solovey

The paper discusses an effective and simple approach to preliminary long-term predictive modelling to the estimation of the effects of predicted climate change on groundwater resources in aquifer recharged by rain infiltration for the end of the $21 \mathrm{st}$ century. The groundwater resources in an analysed catchment were assessed based on predicted precipitation and air temperature from seven climate change projections in two sets of the Intergovernmental Panel on Climate Change (IPCC) greenhouse gas emission scenarios (SRES), associated with various regional climate models (RCM). The predicted groundwater resources were obtained by diminishing the predicted renewable resources by recent environmental flows in a river dewatering the catchment. The predicted reserve was assessed taking into account the forecasted groundwater abstraction. The study revealed that the predicted groundwater reserve depended on the assumed prediction model, based on particular SRES and RCM ensembles. The groundwater resources in the study area at the close of the 21st century are expected to considerably decrease when compared to the reference period 1971-1990. The future groundwater reserve assessed by the climate change model based on IPCC emission scenario B2 connected with the regional climate model HIRHAM and regional climate model RCAO, may decrease when compared to the reference period, by 51 or $92 \%$, respectively. In view of the IPCC emission scenario A2 assumptions, this preliminary predictive modelling shows that there may be a shortage of groundwater resources in the analysed catchment in the final decades of the 21 st century.

Key words: climate change, groundwater resources, groundwater reserve, modelling, prediction, recharge, Poland.

\section{INTRODUCTION}

In many regions, groundwater is central to the water-foodenergy-climate nexus (Green, 2016). Groundwater resources are depleted widespread on the Earth (Wada et al., 2010; Taylor et al., 2012), yet available subsurface storage may be key to meeting demand during times of shortage (Green et al., 2011). Groundwater is, and will be, critically important for global food security, ecosystems or human health, setting new challenges for groundwater resources management (Taylor et al., 2012; Gorelick and Zheng, 2015). Excessive extraction where groundwater is slowly renewed is the main cause of fresh groundwater resources depletion, and climate change has the potential to exacerbate the problem in some regions (Aeschbach-Hertig and Gleeson, 2012). This mainly refers to very densely popu-

* Corresponding authors, e-mail: duda@agh.edu.pl

Received: January 4, 2019; accepted: April 18, 2019; first published online: November 15, 2019 lated areas (Liu et al., 2011; Leng et al., 2015). Predicted groundwater resources need to be assessed in the context of atmospheric $\mathrm{CO}_{2}$ enrichment and climate warming trends, even though projections in space and time are uncertain (Green, 2016). The uncertainty of predicted climate change stems mainly from the assumptions and generalization of data in global climate models (GCMs), downscaling methods and hydrological models (Crosbie et al., 2011; Vetter et al., 2017). The development of climate scenarios using downscaling methods is described by Winkler et al. (2011).

Understanding how climate change could affect groundwater systems is a vital component of sound long-term management of our water supplies (Earman and Dettinger, 2011). Climate change impacts on groundwater (mainly recharge of the resources) and has been investigated by various authors (Ng et al., 2010; Earman and Dettinger, 2011; Jackson et al., 2011; Ali et al., 2012; Baruffi et al., 2012; Hiscock et al., 2012; Taylor et al., 2012; Emam et al., 2015; Jaworska-Szulc, 2015; Olichwer and Tarka, 2015; Tillman et al., 2016; Malekinezhad and Banadkooki, 2017). However, these studies did not usually focus on determining groundwater resources by taking into account predicted groundwater demand and the need to preserve environmental flow in rivers. Therefore, effective 
methods of forecasting groundwater reserves with respect to long-term climate change had to be worked out. Crosbie et al. (2011) and Holman et al. (2012) recommended impact studies, based on climate scenarios from multiple GCMs, or regional climate models (RCM) including multiple $\mathrm{CO}_{2}$ emissions scenarios due to uncertainty, especially in a long-term perspective.

Predictive modelling of groundwater resources should at least be worked out for the end of the 21st century, although rough predictions for the 22nd century can also be expected soon. The estimation of groundwater reserves in aquifers recharged by rain infiltration can be treated as projections of the most relevant risks of climate change, relating to freshwater systems. The manner in which the reduction of these risks can be integrated into recent sustainable water management was presented by Döll et al. (2015).

The biggest obstacle encountered while estimating groundwater reserves is the very long-term water demand forecast that is required for changing climate. This type of prediction requires many data sources from various domains (Brown et al., 2013; Meza et al., 2014). Such data are frequently unavailable and some unpredictable factors may also occur in the future, significantly changing the value of the demand. For this reason, detailed prognoses may be difficult to obtain on such a basis. For obvious reasons the forecasts should account for multiple scenarios, as well as in the context of $\mathrm{CO}_{2}$ emissions (Brown et al., 2013). The estimating of groundwater resources should also take into account the ecological welfare of rivers, e.g. to maintain the environmental flow. The latter is important for preserving good conditions in future aqueous ecosystems.

Accordingly, the presented research goal was a multi-scenario predictive modelling of groundwater reserves in the area analysed, under projected warming climate conditions for the years 2080 to 2100 , and using the assumed method of modelling the predicted groundwater reserves. The novelty of this preliminary research is prognostic modelling of reserves of groundwater resources in the distant future, based on available $\mathrm{CO}_{2}$ emission scenarios and RCM for the study area, taking into account forecasted water demand in the future (estimated) and the need to preserve the environmental flow of the river draining the catchment, determined for hydrological conditions from the reference period.

The reference period 1971-1990 adopted by the authors for the initial assessment of possible impacts of climate change using long-term predictive modelling is different from the reference period 1981-2010, which is the basis for the formal determination of the so-called disposable groundwater resources in the balance areas in Poland based on the methodology given by Herbich et al. (2013). Both methodologies differ significantly from the source data, accepted assumptions and the method of solving the task, due to the different purpose to which they are prepared. This is the authors' deliberate intention because the approach to the preliminary long-term prognostic modelling, described in this paper, is only a proposal for research purposes, which also aims at checking whether a similar multi-scenario modelling of the impact of climate change on the reserve of groundwater resources in the distant future is feasible at all.

\section{MATERIALS AND METHODS}

\section{STUDY AREA}

The study area is a lowland part of the Lower Wieprz River catchment, limited by water gauges in Lubartów and Kośmin, and is located in the Central Vistula River basin in eastern Poland (Fig. 1). The area $\left(3899.8 \mathrm{~km}^{2}\right)$ comprises mostly an agricultural plain ( $73 \%$ of the total area) and forests ( $23 \%$ of the total area). In the majority of the Lower Wieprz River catchment, the groundwater system is multi-level: Upper Cretaceous-Neogene-Quaternary (Paczyński and Sadurski, 2007). In the central and south part of the Lower Wieprz River catchment the main useful aquifer is a fractured-porous Upper Cretaceous aquifer consisting of marls and chalk. The aquifer is unconfined and the depth to the groundwater table is $15-50 \mathrm{~m}$. The aquifer is recharged by rainwater infiltrating directly in the outcrop areas or through the Quaternary sediments.

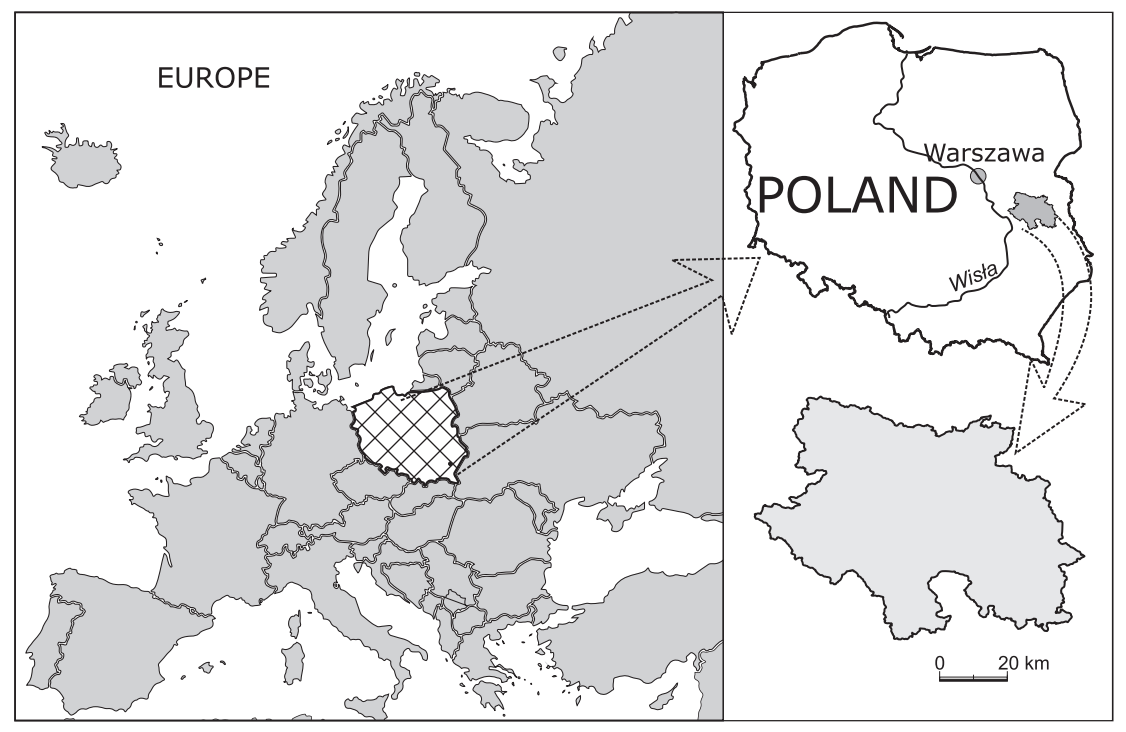

Fig. 1. Study area location 


\section{ASSUMED SETS OF CLIMATE CHANGE FORECASTS}

The climate changes at the end of the 21 st century were predicted by the Intergovernmental Panel on Climate Change (IPCC), based on a few assumed $\mathrm{CO}_{2}$ emission scenarios (SRES) associated with various GCMs (Nakićenović et al., 2000). GCMs are based on a general circulation in the atmosphere and oceans. Particular models significantly differed in the description of physical phenomena. Four groups of SRES predicted a broad range of $\mathrm{CO}_{2}$ emissions, taking into account the assumed global demographic, social, economic and technological development trends. According to predictions by Nakićenović et al. (2000), the global annual emissions of greenhouse gases in IPCC high-emission scenario A2, scenario $\mathrm{A} 1 \mathrm{~B}$, moderate emission scenario $\mathrm{B} 2$, and scenario B1 could be 29.1 gigatonnes of carbon (GtC), 13.5, 13.3 and $4.2 \mathrm{GtC}$, respectively. No probability of occurrence was established for particular SRES

The predictive modelling of reserves of groundwater resources in the analysed catchment was made by the authors based on climate change projections in the final decades of the 21 st century. The forecast relied on predicted precipitation and air temperature data obtained with two sets of SRES, joined by various climate models. The first set was worked out for Poland (Miętus and Wibig, 2011), and the other one for Europe (Ciscar et al., 2009). Miętus and Wibig (2011) predicted climate changes in Poland for the years 2011-2030 and 2081-2100 and compared them with the reference period 1971-1990 for three SRES: A1B, B1 and A2. The climate model was based on an $\mathrm{RCM}$, worked out using the statistical-empirical downscaling method, based on averaged results of two GCMs (i.e. ECHAM- 5 and HadCM3). Ciscar et al. (2009) projected climate changes in Europe for the years 2071-2100 and compared them with the reference period 1961-1990 for four variants, uniting SRES A2 and B2 with two RCM, i.e. HIRHAM (Christensen et al., 2007) and RCAO, both stemming from GCMs HadAM3h/HadCM3 and ECHAM4/OPYC3, respectively.

\section{CONTEMPORARY GROUNDWATER RESOURCES}

The natural groundwater resources should be used taking into account the environmental requirements. It was assumed that the groundwater resources possible to use $(A)$ would be equal to the difference in the average annual renewable resources, i.e. groundwater recharge, and environmental flow in the river being the basis for drainage of the analysed catchment:

$$
A=A_{r}-F_{\text {env }}
$$

where: $A_{r}$ - renewable groundwater resources, and $F_{\text {env }}-$ environmental flow.

The renewable groundwater resources in the basin are approximately equal to the amount of recharge (rainfall infiltration) - determined by various methods. However, the environmental flow of the river can be determined mainly by the hydraulic method. Therefore, in order to maintain compatibility of the methods of determination of both variables, it was assumed that the renewable groundwater resources would also be determined by the hydraulic method.

The magnitude of renewable groundwater resources $\left(A_{r}\right)$ in the catchment over the reference period (1971-1990) was as- sessed by the authors in a simplified manner, assuming that the average inflow of water from the recharge in the catchment over a long-term period equals an average groundwater outflow to the river, i.e. river baseflow. The groundwater outflow to the river can be determined based on water gauge indications in observation profiles across the river, for example by a river flow hydrograph analysis. However, for prognostic analyses, an assessment based on long-term observations is necessary. Therefore, the Kille hydraulic method (Kille, 1970), which is based on statistical analysis of river flow gauging, was used as more effective for determining groundwater outflow to the river in a multi-annual period. In this method, the average groundwater outflow to the river was defined as a median with minimum monthly stream flows in the analysed period, thus

$$
A_{r}=H_{g}=\sigma L Q_{m}
$$

where: $H_{g}$ - groundwater outflow to the river, and $\sigma L Q_{m}-$ median of the minimum monthly stream flows.

The authors assume that, in a many-year perspective, the statistical distribution of the minimum monthly stream flows in the successive months of the analysed period is not normal; it approximates to log-normal. The log-normal distribution is caused by increasingly frequent extreme phenomena, e.g. massive floods. It is possible that such extreme flows will be more frequent with the occurrence of climate change. However, these high flows generally do not affect the increase of groundwater outflow to the river. For this reason, it is recommended to assume a median, not an arithmetic mean from the data population.

Environmental protection requires maintaining environmental flow, i.e. the flow regime that is required in a river to achieve desired ecological objectives. This applies to the amount of water that should be left in the watercourse for biological and ecological reasons (Acreman, 2016). A review of environmental (ecological) flow assessment methodologies is given, among others, by Tharme (2003), Acreman (2016) and Hao et al. (2016). Hydraulic methods also may be used to calculate the environmental flow, in which the amount of this flow is identified with some characteristic flow of the river. These methods are characterized by the ease of obtaining reliable data and their statistical elaboration. The characteristic flow, for example minimal annual streamflow, is selected to meet the environmental criteria adopted by the authors of the given method, usually hydro-biological criteria - based on ensuring conditions for survival of various aquatic ecosystems and organisms.

In Poland, works leading to the implementation of a uniform method of environmental flow assessment, proposed by Grela et al. (2018), have been finished by 2018, nevertheless other analytical studies in this subject were also ongoing (e.g., Madej, 2018; Parasiewicz et al., 2018; Pusłowska-Tyszewska and Tyszewski, 2018). For needs of herein described preliminary long-term predictive modelling, the environmental flow $\left(F_{\text {env }}\right)$ in the Wieprz River in the reference period was estimated in a simplified way by the hydraulic method as a median of the minimal annual stream flows $\left(L Q_{a}\right)$ in the reference period:

$$
F_{\text {env }}=\sigma L Q_{a}
$$

This characteristic flow was accepted by the authors as a criterion for the estimation of environmental flow because many years of observations have shown that during these lowest flows, ecosystems and aquatic fauna have survived in good condition until today, under the hydrological conditions of the 
temperate climate usually found in most of Europe. However, this does not apply to regions with periodic rivers. The reason for choosing the median instead of the arithmetic mean from a set of data is analogous to the case of the average groundwater outflow to the river.

\section{RESERVE OF CONTEMPORARY GROUNDWATER RESOURCES}

The reserve of groundwater resources was determined on the basis of the groundwater balance:

$$
B_{A}=A-U
$$

where: $B_{A}$ - reserve of groundwater resources, and $U$-groundwater abstraction.

\section{PREDICTED PRECIPITATION, AIR TEMPERATURE AND EVAPORATION}

The average annual precipitation and air temperature in the study area for the final decades of the 21st century were assessed by the authors by making corrections to the average annual precipitation and temperatures for the period from 1971 to 1990. The corrections were carried out according to the predicted climate changes in Poland (Miętus and Wibig, 2011) and in Europe (Ciscar et al., 2009).

The predicted annual terrain evaporation was established with the Pardé nomogram, based on average annual precipitation and air temperature, as projected by Ciscar et al. (2009) and Miętus and Wibig (2011. The approximate estimation of evaporation was accepted as being sufficient after taking into account (i) the degree of uncertainty and generalization of data in the study area, acquired with RCM (these, in turn, were obtained by the downscaling method from GSMs), and (ii) the degree of uncertainty of SRES predictions. For obtaining spatial distributions of predicted precipitation and terrain evaporation in the study area, point data were interpolated by the authors with the inverse distance method.

\section{PREDICTED RENEWABLE GROUNDWATER RESOURCES}

The hydraulic method does not provide the possibility of determining future renewable groundwater resources, as it does not reliably determine the future streamflow - this is due to the uncertainty of climate change. The infiltration method (Staśko et al., 2012; Tarka et al., 2017) also cannot be used for predicting groundwater resources in the future because the empirical value of the effective precipitation infiltration coefficient for particular near-surface soils depends on the evaporation intensity which, in turn, depends on air temperature. With increasing global warming, evaporation may change (Lorenz et al., 2010) and, therefore, effective infiltration coefficient values determined at present may change too. There is no reliable formula correlating effective precipitation infiltration coefficients for particular soils with temperature. These problems mean that groundwater recharge in the distant future will be assessed by new methods, making use of very complex statistical calculations and sophisticated prediction models (Tillman et al., 2016).

Taking into account both the high uncertainty involved in predicting future climate change, performed with climate mod- elling methods (Crosbie et al., 2011), and very general SRES assumptions, the authors of the presented studies consider it is acceptable to apply a simplified method for predictive modelling of groundwater recharge. The modelled groundwater recharge, i.e. expected renewable groundwater resources, was established on the basis of simplified water balance in the catchment and on the assumption that groundwater recharge is equal to groundwater outflow to the river draining the catchment. This simplification was considered acceptable as part of the proposed approach in preliminary long-term predictive modelling of groundwater resource reserves in the perspective of the ongoing global climate change on the Earth and the overall uncertainty associated with the probability level of occurrence of particular SRES, or another scenario which is indefinite today.

$$
A_{r(p r)}=R_{(p r)}=H_{g(p r)}=P_{(p r)}-E_{(p r)}-H_{p(p r)}
$$

where: $A_{r(p r)}$ - predicted groundwater renewable resources, $R_{(p r)}-$ predicted groundwater recharge, $H_{g(p r)}$ - predicted groundwater outflow to the river, $P_{(p r)}$ - predicted precipitation, $E_{(p r)}$ - predicted evaporation, and $H_{p(p r)}$ - predicted surface runoff.

Surface runoff is part of the total runoff appearing in the inclined terrain surface during rainfall or rapid thawing. Terrain inclination is constant unlike the frequency of rainfall and its intensity. However, to enable us to determine the precipitation structure in the distant future, it was assumed by the authors (for simplicity) that the ratio of surface runoff to groundwater outflow in 2071-2100 $\left(h_{(p r)}\right)$ would be the same as in the reference period 1971-1990, i.e.

$$
h_{(p r)}=\frac{H_{p(p r)}}{H_{g(p r)}}=h=\frac{H_{p}}{H_{g}}
$$

hence

$$
H_{p(p r)}=h \cdot H_{g(p r)}
$$

where: $H_{p(p r)}$ - average annual surface runoff in the period 2071-2100, $H_{g(p r)}$ - average annual groundwater outflow in 2071-2100, $h$ - ratio of surface runoff to groundwater outflow in the reference period, $H_{p}$ - average annual surface runoff in the reference period, and $H_{g}$ - average annual groundwater outflow in the reference period.

The components of water balance presented in formula [5] are spatially variable in the catchment; therefore coefficient $(h)$ must also change spatially. The spatial distribution of the ratio of surface runoff to groundwater outflow in the reference period $(h)$ was established by GIS. For this purpose, a spatial distribution of precipitation, evaporation and recharge defined for the years 1971-1990 was used, according to the water balance equation and formula [6]:

$$
H_{p}=P-E-H_{g}
$$

hence

$$
h=\frac{P-E-H_{g}}{H_{g}}
$$

where: $P$ - average annual precipitation in the reference period, and $E$ - average annual evaporation in the reference period. 
At the first stage of determining predicted renewable groundwater resources, a map of spatial variability of coefficient (h) was worked out. This map was preceded by a groundwater recharge map and the latter was assumed to equate to the map of groundwater outflow from the catchment. For determining the recharge rate, the infiltration method was applied. This method allowed for determining the fraction of the precipitation that recharges the aquifer:

$$
H_{g}=R=P \cdot \alpha \cdot \beta \cdot \gamma
$$

where: $R$ - average annual recharge, $P$ - average annual precipitation, $\alpha$ - infiltration coefficient (which depends on the lithology of near-surface soils and rocks), $\beta$ - land cover-dependent coefficient, and $\gamma$ - terrain inclination-dependent coefficient.

The assumption of the dependence [10] is a simplification, because the groundwater outflow $\left(H_{g}\right)$ from the catchment is in fact not equal to the groundwater recharge $(R)$, but it should be defined by the formula given by Herbich et al. (2013):

$$
H_{g}=R-E T D-U_{n r}+W G
$$

where: ETD - evapotranspirational drainage of groundwater in the area of a continuously or periodically wet marsh terrace with a depth to the water table less than about $1.5 \mathrm{~m}, U_{n r}-$ non-returnable abstraction of groundwater in the catchment, and WG - balance of groundwater exchange (inflow-outflow) across the catchment boundaries.

Although the accepted simplification (dependence [10]) leads to inaccuracies in the estimation of groundwater resources and the state of their reserves in the distant future, it was considered acceptable under the preliminary long-term prognostic modelling, and in the absence of data regarding the remaining components of this balance, in addition to the recharge.

Maps of the spatial variability of mean annual precipitation and evaporation in the years 1971-1990 prepared by the authors of this study were based on the results of precipitation and temperature measurements. In order to obtain the spatial distribution of these factors, point data were interpolated with the inverse distance method (Fig. 2A, B). In order to obtain the spatial variability of infiltration coefficient $\alpha$ (which depends on the lithology of near-surface soils and rocks), a geological map of Poland at a scale of 1:200,000 was used. Specific values of infiltration coefficient a were assumed for particular soils appearing in the terrain: 0.07 was assumed for mud, silt and clay; 0.11 for loam and loamy alluvia; 0.13 for loess; 0.21 for sand with gravel; 0.27 for fractured marl and chalk (Fig. 2C).

The map of catchment coverage was constructed by the authors on the basis of the CORINE Land Cover database (clc.gios.gov.pl). The project CORINE Land Cover in Poland was operated by the Prime Inspectorate of Environmental Protection and executed by the Institute of Geodesy and Cartography. The following values of coefficient $\beta$ depended on the land cover and were assumed to be: 0.9 for forests and swamps, 1.0 for urbanized and industrial areas, municipal green lands, agricultural land, arable land, permanent crops, meadows and mixed crop culture zones (Fig. 2D). A map of terrain inclination was based on a digital terrain model of the area, with a $250 \mathrm{~m}$ resolution (srtm.csi.cgiar.org). The following values of coefficient $\gamma$ depended on the terrain inclination and were assumed to be: 1.0 for angles $<0.50^{\circ} ; 0.95$ for angles between $0.5^{\circ}$ and $2.0^{\circ}$; and 0.90 for angles 2 to $4^{\circ}$ (Fig. 2E).
Based on GIS calculations (according to equation [10]) a map of the average annual precipitation infiltration was obtained for the period 1971-1990, i.e. groundwater recharge, for the zones with particular near-surface soils and rocks (Fig. 2F).

The equation for water balance [5] was then transformed, taking into account the coefficient of proportionality $(h)$ between forecasted surface runoff and groundwater outflow

$$
H_{g(p r)}=P_{(p r)}-E_{(p r)}-\left(h \cdot H_{g(p r)}\right)
$$

therefore

$$
(h+1) \cdot H_{g(p r)}=P_{(p r)}-E_{(p r)}
$$

and thus:

$$
A_{r(p r)}=R_{(p r)}=\frac{P_{(p r)}-E_{(p r)}}{h+1}
$$

The spatial distribution of the factors used for forecasting the mean annual groundwater recharge by particular near-surface soils in the analysed catchment is exemplified by the climate change scenario based on ensemble SRES A2 with climate model RCAO (see Fig. $3 A-C$ ). The predicted recharge in the zones of occurrence of individual soils is shown in Figure 3D.

For obtaining predicted groundwater recharges in assumed climate change scenarios within the zones of particular near-surface soils, a map of their occurrence in the catchment area was used. The renewable groundwater resources in the whole of the catchment were then forecast using the equation:

$$
A_{r(p r)}=\sum_{i=1}^{n} R_{(p r) i} \cdot F_{i}
$$

where: $A_{r(p r)}$ - predicted groundwater renewable resources; $R_{(p r) i}-$ predicted groundwater recharge in the zone of any given near-surface soil or rock occurrence, $F_{i}$ - surface area of a given lithological zone.

The long-term predictive models of renewable groundwater resources were performed by the authors (i) for the years 2081-2100 with a set of three SRES (B1, A2 and A1B), joined by an RCM, averaged from GCMs ECHAM5 and HadCM3, and (ii) for the period 2071-2100 for a set of two SRES (B2 and A2), each one associated with RCM HIRHAM and RCAO.

\section{PREDICTED ENVIRONMENTAL FLOW}

While determining the environmental flow of a river in the final decades of the 21st century, the authors assumed that the value would remain the same as in the reference period, i.e. 1971-1990. This assumption guarantees proper conditions for the preservation of aqueous ecosystems if the flows in the river were smaller in the future, e.g. due to possible droughts and higher water abstraction in the catchment.

\section{PREDICTED GROUNDWATER ABSTRACTION}

The predicted groundwater abstraction in the final decades of the 21st century was established in two stages based on available literature. At the first stage, the projected groundwater 


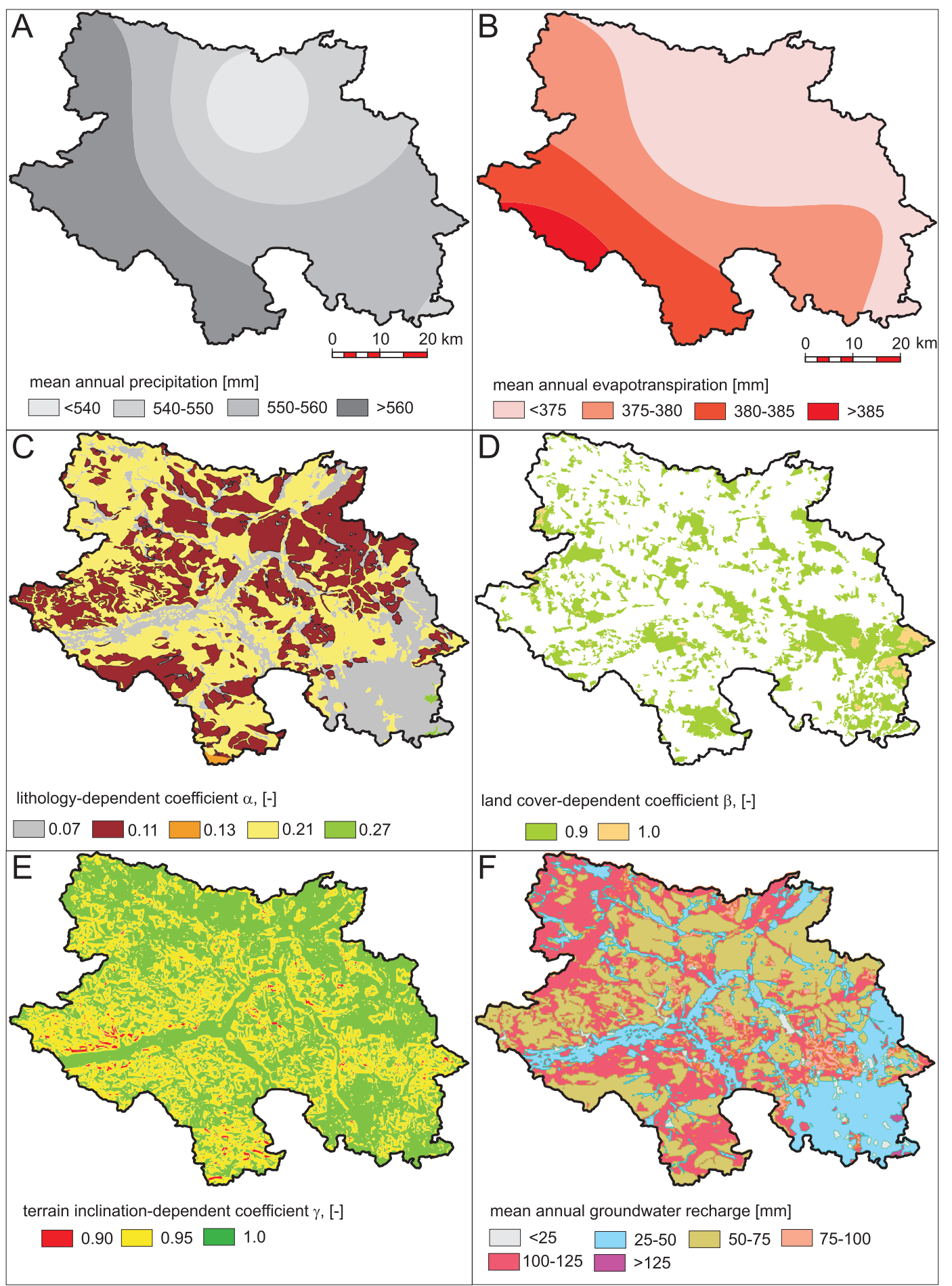

Fig. 2. Spatial distribution of factors used for obtaining coefficient of proportionality $(h)$ between surface runoff and groundwater outflow for the years 1971-1990 (A-E), and groundwater recharge in the zones of particular near-surface soils and rocks, for the years 1971-1990 (F)

abstraction of $212,400 \mathrm{~m}^{3} / \mathrm{d}$ was assumed for the whole Wieprz River catchment in the year 2030, based on the work by Herbich and Przytuła (2012). This is the only available source material providing any forecast for groundwater abstraction in Poland. This forecast was based on a coefficient, increasing the actual abstraction value of 2009 by $15 \%$. According to the authors of the forecast, this coefficient stands for the increase for water demand by present and future users, provided that wa- ter-saving technologies are involved. The projected abstraction in the analysed catchment, being part of the Wieprz River catchment, was calculated like in the case of contemporary abstraction, i.e. based on the proportion between the surface area of the analysed catchment and the whole Wieprz River catchment. However, the amount of groundwater abstraction assumed in this way is over-estimated and is subject to a significant error, resulting from the fact that the largest groundwater 

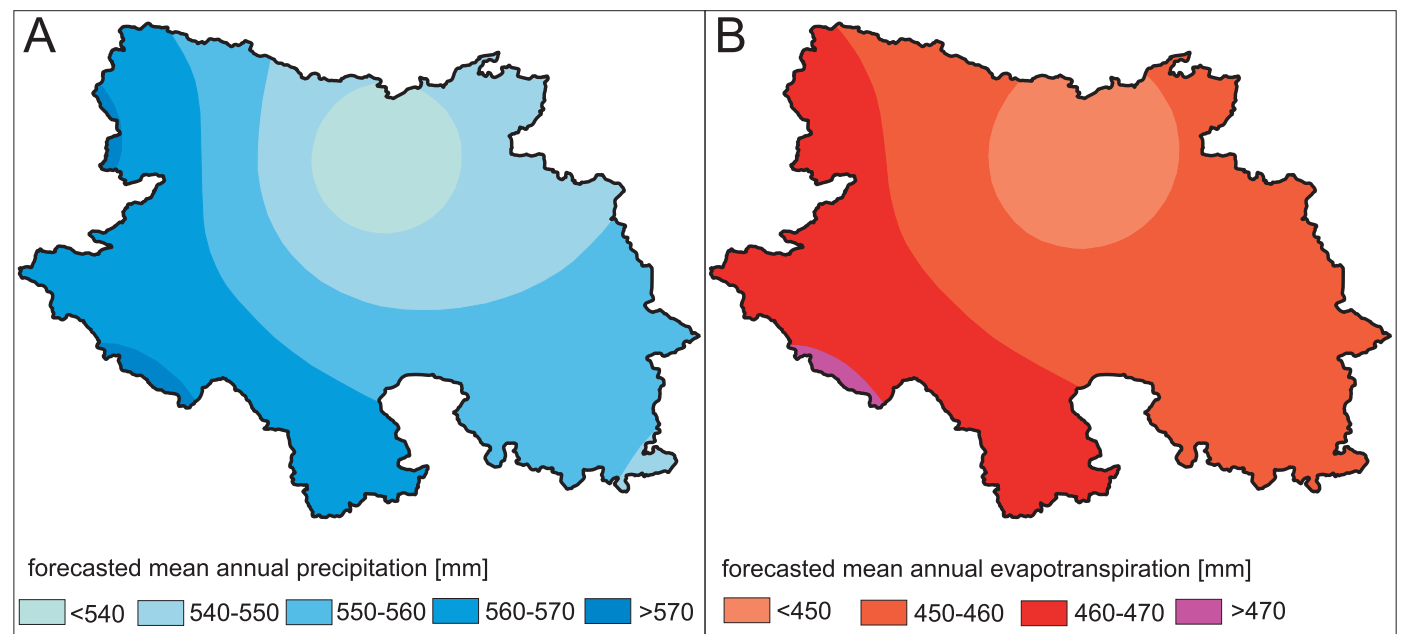

forecasted mean annual evapotranspiration [mm]

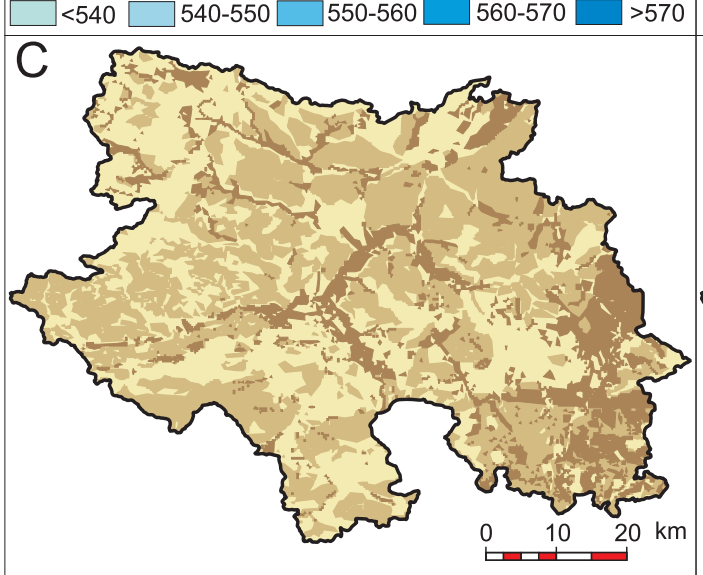

$\square<450 \square 450-460 \square 460-470 \square>470$

coefficient $h$ appointed for period 1971-1990, [-]

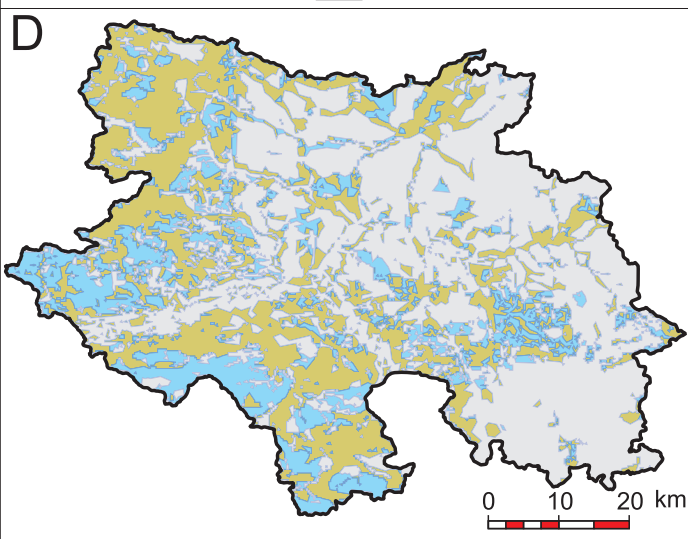

forecasted mean annual groundwater recharge $[\mathrm{mm}]$

$\square<2 \square 2-4 \square>4$

$\square<25 \square 25-50 \square>50$

Fig. 3. Spatial distribution of factors used for predicting mean annual groundwater recharge for the years 2071-2100 for ensemble SRES A2 with RCM RCAO (A-C), and forecasted recharge for 2071-2100 in the zones of occurrence of particular soils (D)

abstraction in the whole Wieprz River catchment is concentrated in several major cities located outside the study area.

At the second stage, a possible further increase of water demand in the final decades of the 21st century was accounted for. Accordingly, a coefficient increasing the abstraction forecast for the year 2030 by next $15 \%$ was assumed arbitrarily, due to the lack of other reliable forecasts:

$$
U_{(p r)}=1.15 \cdot \frac{F}{F_{C}} \cdot U_{(p r) c}
$$

where: $U_{(p r)}$ - predicted groundwater abstraction in the analysed catchment, $U_{(p r) c}$ - predicted groundwater abstraction in 2030 in the whole Wieprz River catchment, $F$ - area of the analysed catchment, and $F_{c}$ - area of the Wieprz River catchment.

\section{PREDICTED RESERVE OF GROUNDWATER RESOURCES}

The predicted reserve of groundwater resources in the analysed catchment were calculated on the basis of the water management balance:

$$
B_{A(p r)}=A_{(p r)}-U_{(p r)}
$$

and so

$$
B_{A(p r)}=A_{r(p r)}-F_{e n v}-U_{(p r)}
$$

where: $B_{A(p r)}$ - predicted reserve of groundwater resources, $A_{(p r)}-$ predicted groundwater resources, $U_{(p r)}$ - predicted groundwater abstraction, $A_{r(p r)}$ - predicted renewable groundwater resources, and $F_{\text {env }}-$ environmental flow of a river.

\section{RESULTS}

\section{CONTEMPORARY GROUNDWATER RESOURCES}

This preliminary long-term predictive modelling showed that contemporary renewable groundwater resources $\left(A_{r}\right)$ in the analysed catchment (defined as a median of the minimum monthly stream flows in the reference period 1971-1990) totalled $9.3 \mathrm{~m}^{3} \mathrm{~s}^{-1}$ (Fig. 4). The environmental flow $\left(F_{\text {env }}\right)$ of the river dewatering the study area (as a median of the minimum 


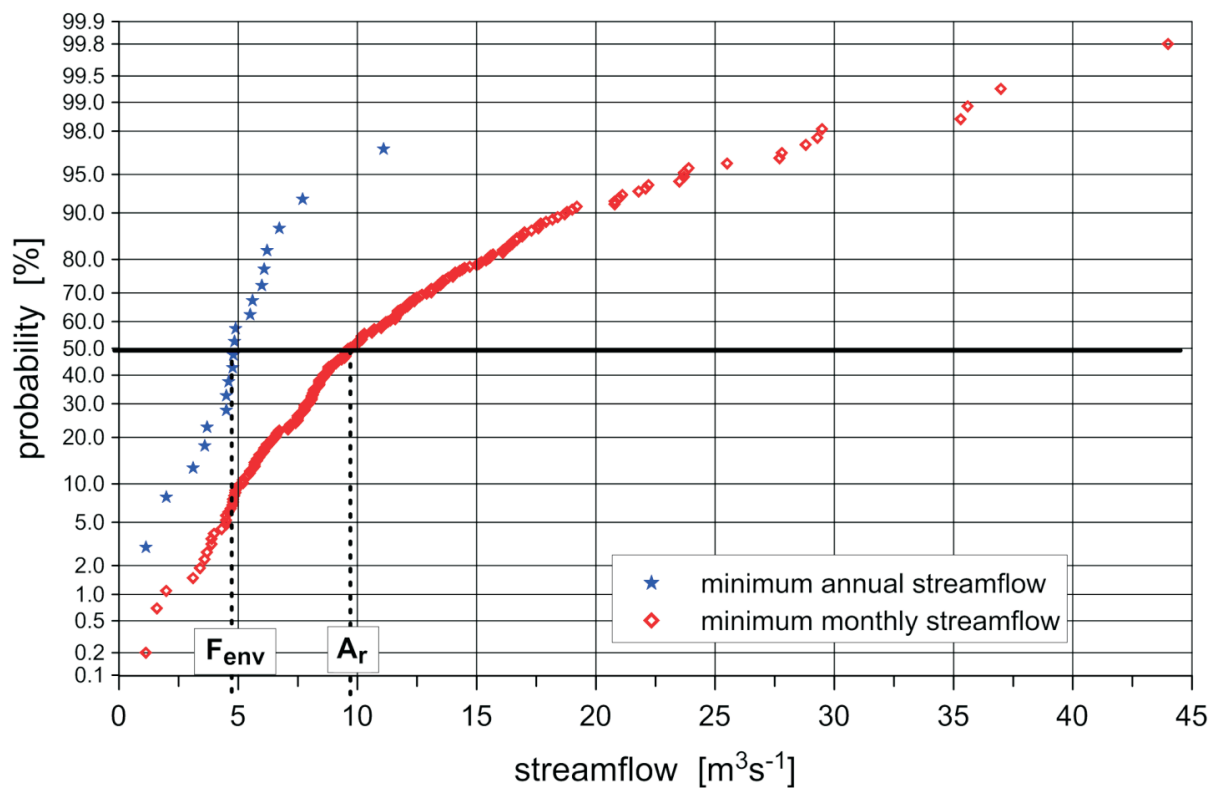

Fig. 4. Renewable groundwater resources $\left(A_{r}\right)$ and environmental flow in Wieprz River $\left(F_{\text {env }}\right)$ in the period 1971-1990 (based on data from IMGW, 2018)

annual stream flows) was $4.6 \mathrm{~m}^{3} \mathrm{~s}^{-1}$. The contemporary groundwater resources $(A)$ in the analysed catchment were defined by equation [1], and were found to be $4.7 \mathrm{~m}^{3} / \mathrm{s}$.

\section{RESERVE OF CONTEMPORARY GROUNDWATER RESOURCES}

The contemporary daily water abstraction in the analysed catchment was estimated at $68,659 \mathrm{~m}^{3}$, i.e. $0.8 \mathrm{~m}^{3} \mathrm{~s}^{-1}$. However, this amount of groundwater abstraction assumed in this preliminary predictive modelling is over-estimated and is subject to a significant error, resulting from the fact that the largest groundwater abstraction in the whole Wieprz River catchment is concentrated in several major cities located outside the study area. The reserve of groundwater resources $\left(B_{A}\right)$ in the catchment in 1971-1990 (defined by equation [4]) may be estimated at $3.9 \mathrm{~m}^{3} \mathrm{~s}^{-1}$.

\section{PREDICTED PRECIPITATION, AIR TEMPERATURE AND EVAPORATION}

Considering the climate change forecast for Poland (Miętus and Wibig, 2011), the average annual precipitation for SRES B1 and A2 in the years 2081-2100 in the analysed catchment could change by 0 to $+2.5 \%$, when compared to values obtained in the years 1971-1990. In scenario A1B, the precipitation is expected to increase by about $2.5 \%$. The annual air temperature in the analysed catchment in SRES B1, A1B and $\mathrm{A} 2$ is expected to increase by approximately $0.35,0.50$ and $0.52^{\circ} \mathrm{C}$, respectively, when compared to the reference period.

The climate change projection for Europe (Ciscar et al., 2009) allowed for stating that the average annual precipitation in the analysed catchment in the years 2071-2100 would change from -5 to $+10 \%$ of precipitation in 1961-1990, de- pending on the assumed ensembles of SRES with given RCM. The average annual temperature in the catchment area was also expected to increase from 4 to $5^{\circ} \mathrm{C}$ for ensemble SRES A2 with regional climate model HIRHAM, and from 5 to $6^{\circ} \mathrm{C}$ for ensemble SRES A2 with regional climate model RCAO. The average annual temperature may increase from 2 to $3^{\circ} \mathrm{C}$ for SRES B2 joined with model HIRHAM, and from 4 to $5^{\circ} \mathrm{C}$ for SRES B2 joined with model RCAO.

The projected average annual precipitation, air temperature and evaporation in the study area, forecasted based on projected changes of precipitation and temperature in Poland (Miętus and Wibig, 2011) and in Europe (Ciscar et al., 2009), are shown in Table 1.

\section{PREDICTED RENEWABLE GROUNDWATER RESOURCES}

The spatial distribution of predicted average annual groundwater recharge in the study area at the end of the 21st century, obtained by the authors based on assumed ensembles SRES with RCM, is illustrated in Figures 5 and 6.

The modelling reveals that the predicted renewable groundwater resources in the analysed catchment for the period 2081-2100, taking into account climate warming conditions forecasted for Poland by Miętus and Wibig (2011), may equal $8.3 \mathrm{~m}^{3} \mathrm{~s}^{-1}$ for SRES B1 and A2, and $8.5 \mathrm{~m}^{3} \mathrm{~s}^{-1}$ for SRES A1B (Table 2). The authors have also found that in the case of the climate change predicted for Europe for the years 2071-2100 by Ciscar et al. (2009), the expected renewable groundwater resources may be 7.6 and $5.3 \mathrm{~m}^{3} \mathrm{~s}^{-1}$ for SRES B2 and A2 associated with RCM HIRHAM, respectively. If SRES was associated with RCM RCAO, these values might be 6.0 and $4.7 \mathrm{~m}^{3} \mathrm{~s}^{-1}$, respectively. The renewable groundwater resources predicted in this modelling for the study area, defined as an average of the results from all models, may be $7 \mathrm{~m}^{3} \mathrm{~s}^{-1}$. 
Predicted average annual precipitation $[\mathrm{mm}]$, air temperature $\left[{ }^{\circ} \mathrm{C}\right]$ and evaporation $[\mathrm{mm}]$ in the analysed catchment in the final decades of the 21 st century

\begin{tabular}{|c|c|c|c|c|c|c|c|c|}
\hline \multirow{3}{*}{$\begin{array}{l}\text { Meteo } \\
\text { station }\end{array}$} & \multirow{3}{*}{$\begin{array}{c}\text { 1971-1990 } \\
\text { Precipitation* } \\
\text { Temperature* } \\
\text { Evaporation }\end{array}$} & \multicolumn{3}{|c|}{$2081-2100$} & \multicolumn{4}{|c|}{$2071-2100$} \\
\hline & & B1 & $\mathrm{A} 2$ & A1B & B2 & A2 & B2 & $\mathrm{A} 2$ \\
\hline & & \multicolumn{3}{|c|}{ RCM averaged from ECHAM5 and HadCM3 } & \multicolumn{2}{|c|}{ HIRHAM } & \multicolumn{2}{|c|}{ RCAO } \\
\hline Lublin-Radawiec & $\begin{array}{r}573.6 \\
7.5 \\
385.0 \\
\end{array}$ & $\begin{array}{r}573.6 \\
7.8 \\
390.0 \\
\end{array}$ & $\begin{array}{r}580.8 \\
8.0 \\
397.0 \\
\end{array}$ & $\begin{array}{r}588.0 \\
8.0 \\
400.0 \\
\end{array}$ & $\begin{array}{r}616.6 \\
10.0 \\
450.0 \\
\end{array}$ & $\begin{array}{r}573.6 \\
12.0 \\
455.0 \\
\end{array}$ & $\begin{array}{r}573.6 \\
12.0 \\
455.0 \\
\end{array}$ & $\begin{array}{r}573.6 \\
13.0 \\
470.0 \\
\end{array}$ \\
\hline $\begin{array}{l}\text { Radzyń } \\
\text { Podlaski }\end{array}$ & $\begin{array}{r}534.4 \\
7.4 \\
370.0 \\
\end{array}$ & $\begin{array}{r}534.4 \\
7.7 \\
375.0 \\
\end{array}$ & $\begin{array}{r}541.1 \\
7.9 \\
380.0 \\
\end{array}$ & $\begin{array}{r}547.8 \\
7.9 \\
385.0 \\
\end{array}$ & $\begin{array}{r}574.5 \\
9.9 \\
428.0 \\
\end{array}$ & $\begin{array}{r}534.4 \\
11.9 \\
431.0 \\
\end{array}$ & $\begin{array}{r}574.5 \\
11.9 \\
450.0 \\
\end{array}$ & $\begin{array}{r}534.4 \\
12.9 \\
445.0 \\
\end{array}$ \\
\hline Bezek & $\begin{array}{r}537.8 \\
7.4 \\
370.0 \\
\end{array}$ & $\begin{array}{r}537.8 \\
7.7 \\
375.0 \\
\end{array}$ & $\begin{array}{r}544.5 \\
7.9 \\
382.0 \\
\end{array}$ & $\begin{array}{r}551.3 \\
7.8 \\
385.0 \\
\end{array}$ & $\begin{array}{r}578.1 \\
9.9 \\
430.0 \\
\end{array}$ & $\begin{array}{r}537.8 \\
11.9 \\
433.0 \\
\end{array}$ & $\begin{array}{r}537.8 \\
11.9 \\
435.0 \\
\end{array}$ & $\begin{array}{r}537.8 \\
12.9 \\
450.0 \\
\end{array}$ \\
\hline Siedlce & $\begin{array}{r}530.1 \\
7.0 \\
365.0 \\
\end{array}$ & $\begin{array}{r}530.1 \\
7.3 \\
365.0 \\
\end{array}$ & $\begin{array}{r}536.8 \\
7.5 \\
372.0 \\
\end{array}$ & $\begin{array}{r}536.8 \\
7.5 \\
372.0 \\
\end{array}$ & $\begin{array}{r}569.9 \\
9.5 \\
417.0 \\
\end{array}$ & $\begin{array}{r}530.1 \\
11.5 \\
427.0 \\
\end{array}$ & $\begin{array}{r}569.9 \\
11.5 \\
450.0 \\
\end{array}$ & $\begin{array}{r}530.1 \\
12.5 \\
440.0 \\
\end{array}$ \\
\hline Jarczew & $\begin{array}{r}572.2 \\
7.2 \\
380.0 \\
\end{array}$ & $\begin{array}{r}572.2 \\
7.5 \\
385.0 \\
\end{array}$ & $\begin{array}{r}572.2 \\
7.7 \\
388.0 \\
\end{array}$ & $\begin{array}{r}579.3 \\
7.7 \\
390.0 \\
\end{array}$ & $\begin{array}{r}615.1 \\
9.7 \\
442.0\end{array}$ & $\begin{array}{r}572.2 \\
11.7 \\
450.0\end{array}$ & $\begin{array}{r}615.1 \\
11.7 \\
470.0\end{array}$ & $\begin{array}{r}572.2 \\
12.7 \\
465.0\end{array}$ \\
\hline Puławy & $\begin{array}{r}582.8 \\
7.8 \\
395.0\end{array}$ & $\begin{array}{r}582.8 \\
8.1 \\
400.0\end{array}$ & $\begin{array}{r}582.8 \\
8.3 \\
402.0\end{array}$ & $\begin{array}{r}590.1 \\
8.2 \\
405.0\end{array}$ & $\begin{array}{r}626.6 \\
10.3 \\
459.0\end{array}$ & $\begin{array}{r}582.8 \\
12.3 \\
465.0\end{array}$ & $\begin{array}{r}582.8 \\
12.3 \\
465.0\end{array}$ & $\begin{array}{r}582.8 \\
13.3 \\
480.0\end{array}$ \\
\hline
\end{tabular}

B1, B2, A2, A1B - SRES; * - based on http://klimat.pogodynka.pl and https://pl.climate-data.org

\section{PREDICTED GROUNDWATER ABSTRACTION}

The predicted groundwater abstraction in the analysed catchment in the final decades of the 21 st century, calculated by equation [16] may be equal to:

$$
U_{p r}=1.15 \cdot \frac{3899.8}{10490.4} \cdot 212400=90803.5 \frac{\mathrm{m} 3}{\mathrm{~d}}=1.1 \frac{\mathrm{m} 3}{\mathrm{~s}}
$$

\section{PREDICTED RESERVES OF GROUNDWATER RESOURCES}

The groundwater reserves in the final decades of the 21st century, predicted in this preliminary modelling for the analysed climate warming scenarios, are presented in Table 3. In each scenario, the forecasted reserves may diminish when compared to the reserves of the reference period. The authors of the models revealed that the greatest drop in the predictively modelled resources, consequently leading to a deficiency of resources in the predicted groundwater abstraction conditions, are observed for SRES A2 joined with RCM RCAO and HIRHAM. The average decrease of predicted groundwater reserves in the study area, defined with all seven models, may constitute $67 \%$ of the reserves available between 1971 and 1990. The average reserve of groundwater resources predicted in this preliminary modelling may be approximately $1.3 \mathrm{~m}^{3} \mathrm{~s}^{-1}$.

\section{DISCUSSION}

The intrinsic uncertainty that accompanies the climate scenarios and projections makes it complicated to use them as a basis for decision-making (Kristvik et al., 2019). Therefore, the results of preliminary long-term predictive modelling, obtained by the authors, should be treated only as approximate and uncertain. However, despite its obvious uncertainty, it can be stated that the modelling showed that it is feasible - also taking into account estimative forecasted water demand in the future and the need to preserve the environmental flow of rivers. The preliminary modelling has shown that the effect of unavoidable climate changes in the distant future will be a reduction in the amount of groundwater resources available for use. This applies in general to those areas where the forecasts indicate that the climate change will cause an increase in air temperature and evapotranspiration.

The modelling results reveal that the magnitude of the predicted groundwater reserves essentially depends on the assumed future climate model, based on particular SRES joined with given RCM. The authors' predictions resulting from the assumed temperature and precipitation changes, based on future climate models for Europe by Ciscar et al. (2009), showed a possible diminishing of reserves of groundwater resources in the study area. The future reserves of groundwater resources were modelled on the basis of the SRES B2 associated with RCM HIRHAM and RCAO, and show a possible decrease by 

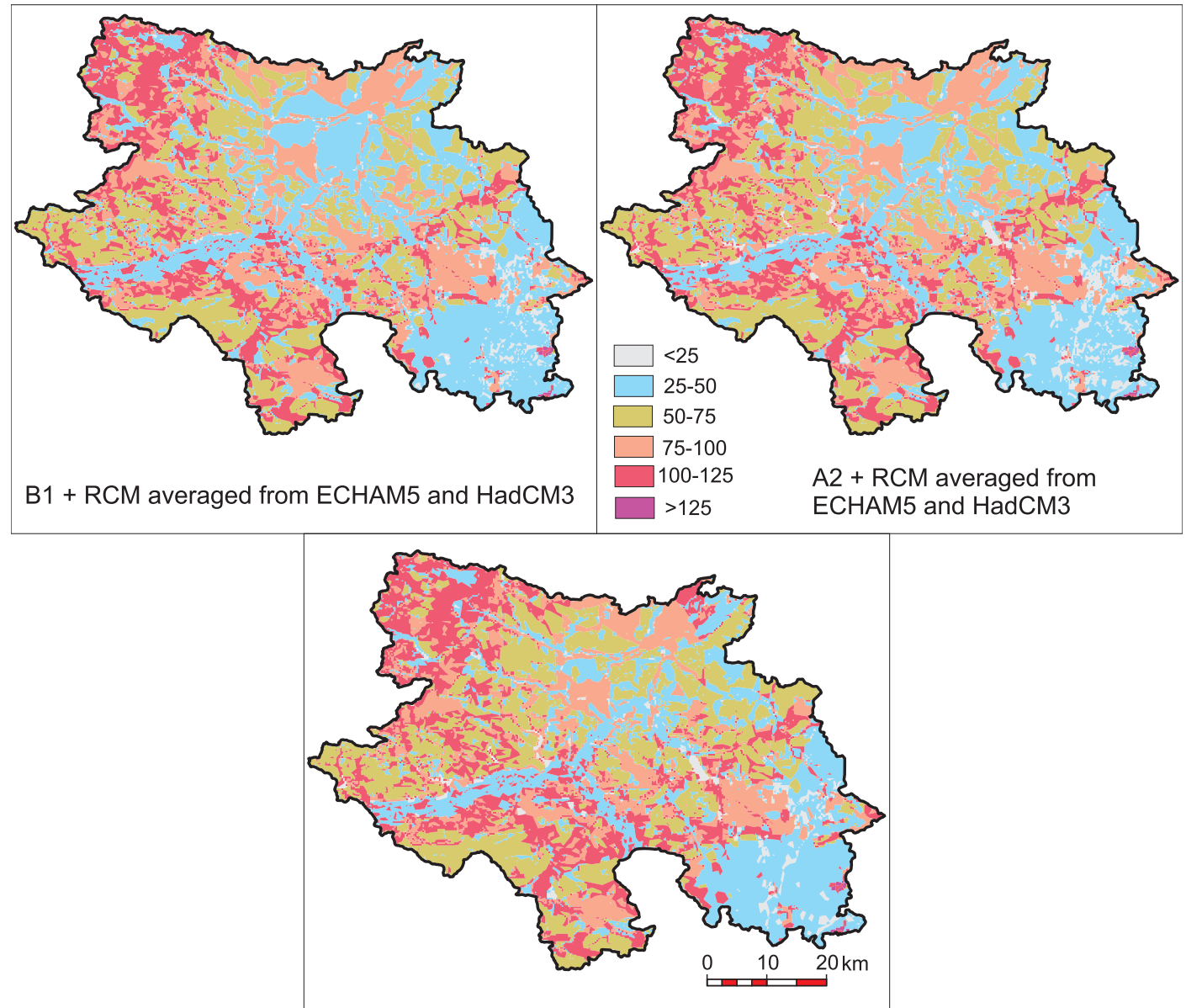

A1B + RCM averaged from ECHAM5 and HadCM3

Fig. 5. Predicted average annual groundwater recharge [mm] for 2081-2100

B1, A2, A1B - SRES; ECHAM5, HadCM3 - global climate model (GCM)

51 and $92 \%$, respectively, when compared to the reference period. However, in line with the SRES A2 assumptions, the obtained forecast shows a possible loss of reserves of groundwater resources in the final decades of the 21 st century. This possible deficiency in reserves may reach $0.4 \mathrm{~m}^{3} \mathrm{~s}^{-1}$ for $\mathrm{RCM}$ HIRHAM conditions or $1.0 \mathrm{~m}^{3} \mathrm{~s}^{-1}$ for RCM RCAO conditions. Such a large difference in forecasts on variant models assumed by the authors stems from the SRES assumption that the human population at the end of the 21 st century will be greater in scenario A2 than in $\mathrm{B} 2$, and that the energy production will be based on fossil fuels. Consequently, higher greenhouse gas emissions occur in scenario A2 than in B2 (Nakićenović et al., 2000). Higher emissions will generate higher temperatures and more evaporation. As a consequence, the reserves of groundwater resources may decrease.

Future changes in the groundwater reserves cannot be clearly defined because the prediction should be based on a very reliable climate change model, which is still not available. Many discrepancies can still be observed between the climate change models being proposed by various authors. The different assumptions adopted for particular GCMs and RCM, various calculation methods and other detailed establishments bring about different results of climate change projections. The differences in the predictions also stem from various downscaling methods from GCMs to RCM, described by
Winkler et al. (2011). The situation becomes even more complicated when we realize that the World's development scenarios differ considerably. It is still the case that none of the SRES even approximately defines the probability of occurrence. Also, we cannot ignore the possibility that a different, today unknown World's development might happen, especially in the distant future, i.e. at the turn of the 21 st and 22 nd centuries. For this reason, the assumption of an average value from the results obtained with various sets of SRES joined with RCM seems to be a reasonable solution (Crosbie et al., 2011; Holman et al., 2012).

Some new research projects make use of a new approach, based on variant forecasts of representative concentration pathways (RCPs) of greenhouse gases for the end of the 21st century (Moss et al., 2010). Further long-term predictive modelling of the groundwater reserves in selected catchments or river basins in Europe should be based on the predicted climate changes, e.g. in the EURO-CORDEX project (Jacob et al., 2014) on ensembles RCM with RCP4.5 and RCP8.5 (Riahi et al., 2011; Thomson et al., 2011).

The amount of water recharging the aquifer from the surface depends on precipitation, its form (e.g., heavy rainfalls do not increase the recharge but contribute to the surface runoff), lithology of near-surface soils, land cover and terrain inclination. The soil type and terrain inclination can be treated as being con- 


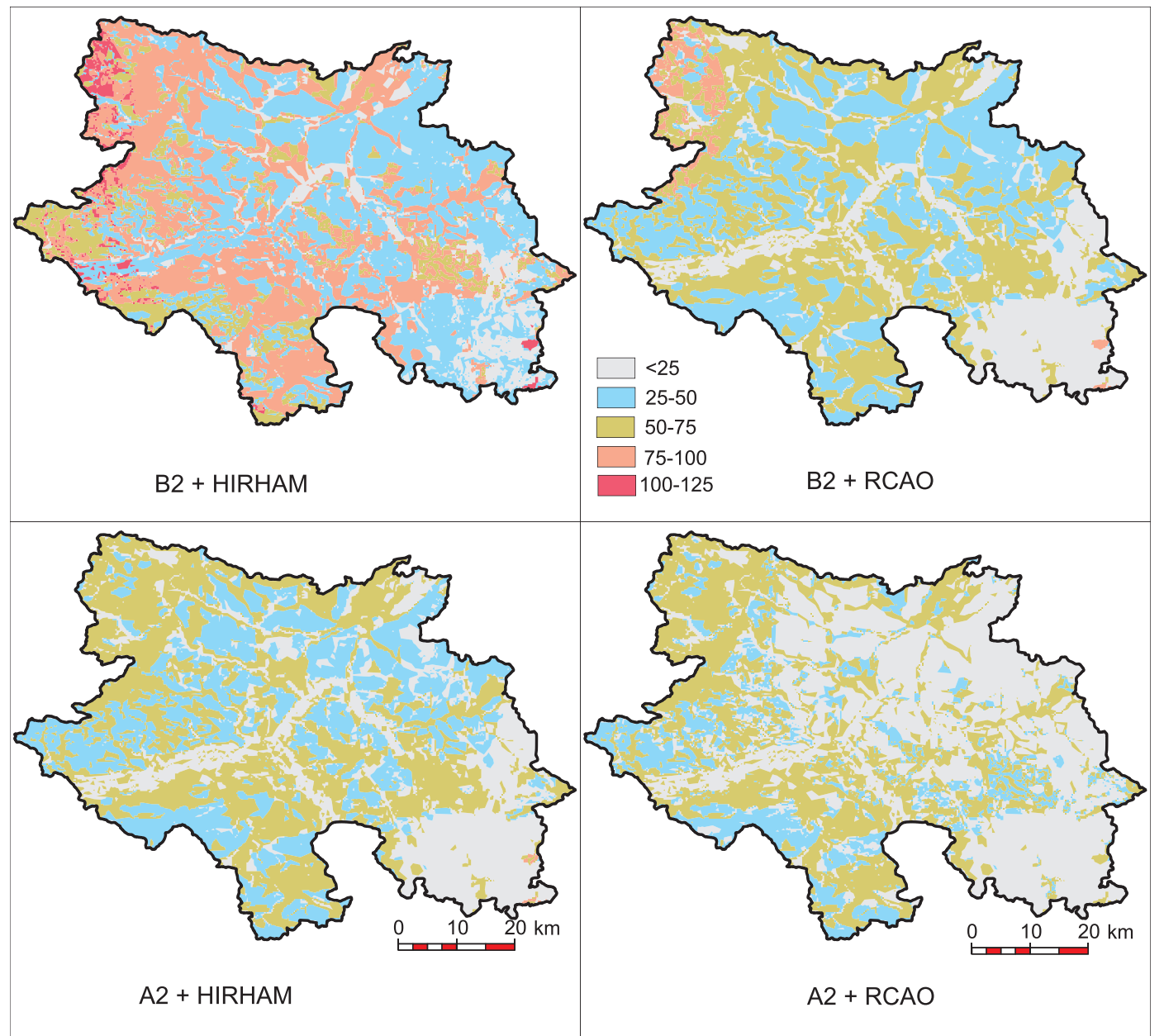

Fig. 6. Predicted average annual groundwater recharge [mm] for 2071-2100

B2, A2 - SRES; HIRHAM, RCAO - regional climate model (RCM)

Predicted renewable groundwater resources in the analysed catchment $\left[\mathrm{m}^{3} \mathrm{~s}^{-1}\right]$

\begin{tabular}{|c|c|c|c|c|c|c|c|}
\hline \multirow{3}{*}{$\begin{array}{l}\text { Near-surface soils } \\
\text { and rocks }\end{array}$} & \multirow{2}{*}{\multicolumn{3}{|c|}{$\begin{array}{c}2081-2100 \\
\text { RCM averaged from ECHAM5 } \\
\text { and HadCM3 }\end{array}$}} & \multicolumn{4}{|c|}{$2071-2100$} \\
\hline & & & & \multicolumn{2}{|c|}{ HIRHAM } & \multicolumn{2}{|c|}{ RCAO } \\
\hline & $\mathrm{B} 1$ & $\mathrm{~A} 2$ & A1B & B2 & $\mathrm{A} 2$ & B2 & $\mathrm{A} 2$ \\
\hline Sand with gravel & 5.07 & 5.07 & 5.20 & 4.67 & 3.28 & 3.71 & 2.86 \\
\hline Loam and loamy alluvia & 2.21 & 2.22 & 2.27 & 2.04 & 1.43 & 1.62 & 1.25 \\
\hline Mud, silt, clay & 0.69 & 0.68 & 0.69 & 0.60 & 0.42 & 0.47 & 0.39 \\
\hline Loess & 0.01 & 0.01 & 0.01 & 0.01 & 0.01 & 0.01 & 0.01 \\
\hline Fractured marl and chalk & 0.28 & 0.28 & 0.29 & 0.26 & 0.18 & 0.20 & 0.16 \\
\hline Total & 8.3 & 8.3 & 8.5 & 7.6 & 5.3 & 6.0 & 4.7 \\
\hline
\end{tabular}

stant in time, but not land cover, especially in the distant future. Another factor that affects effective infiltration is the air temperature, which influences evaporation. The higher the temperature, the larger the evaporation and lower the infiltration. The climate change models that were analysed for the catchment show an increase in average annual air temperature with a simultaneous lack of, or only a slight increase in, precipitation.
This signifies that, in the future, we probably can expect some decrease of groundwater resources.

Another crucial difficulty in assessing the future groundwater reserves is uncertainty in determining future water abstraction. The abstraction value is connected with such factors as: water demand of the inhabitants, the demands of agriculture, particular industries, such as the power industry, water quality, 
Predictions for the final decades of the 21 st century in the analysed catchment

\begin{tabular}{|c|c|c|c|c|c|c|c|c|}
\hline \multirow{2}{*}{\multicolumn{2}{|c|}{$\begin{array}{l}\text { Emission scenario ensemble } \\
\text { with RCM }\end{array}$}} & $A_{r(p r)}$ & $\mathrm{F}_{e n v}$ & $A_{(p r)}$ & $\mathrm{U}_{(p r)}$ & $B_{A(p r)}$ & $\begin{array}{c}B_{A} \\
1971-1990\end{array}$ & \multirow{2}{*}{$\begin{array}{c}\begin{array}{c}\text { Decrease } \\
\text { of reserves }\end{array} \\
{[\%]}\end{array}$} \\
\hline & & \multicolumn{6}{|c|}{$\left[\mathrm{m}^{3} \mathrm{~s}^{-1}\right]$} & \\
\hline A1B & \multirow{3}{*}{$\begin{array}{l}\text { RCM averaged from } \\
\text { ECHAM5 and HadCM3 }\end{array}$} & 8.5 & \multirow{3}{*}{4.6} & 3.9 & \multirow{3}{*}{1.1} & \multirow[t]{3}{*}{2.8} & \multirow{3}{*}{3.9} & 28 \\
\hline B1 & & 8.3 & & 3.7 & & & & 33 \\
\hline $\mathrm{A} 2$ & & 8.3 & & 3.7 & & & & 33 \\
\hline & B2 + HIRHAM & 7.6 & \multirow{4}{*}{4.6} & 3.0 & \multirow{4}{*}{1.1} & 1.9 & \multirow{4}{*}{3.9} & 51 \\
\hline & A2 + HIRHAM & 5.3 & & 0.7 & & $\begin{array}{c}-0.4 \\
\text { (deficiency) }\end{array}$ & & 110 \\
\hline & $\mathrm{B} 2+\mathrm{RCAO}$ & 6.0 & & 1.4 & & 0.3 & & 92 \\
\hline & $\mathrm{A} 2+\mathrm{RCAO}$ & 4.7 & & 0.1 & & $\begin{array}{c}-1.0 \\
\text { (deficiency) }\end{array}$ & & 126 \\
\hline
\end{tabular}

renewable groundwater resources $-A_{r(p r)}$, environmental flow in the river $-F_{\text {env }}$, groundwater resources $-A_{(p r)}$, abstraction $-U_{(p r)}$, reserves of groundwater resources $-B_{A(p r)}$ and reserves for the years 1971-1990 $\left(B_{A}\right)$, and decreasing reserves of groundwater resources in relation to the years 1971-1990

development of water-saving technologies, and the advancement of water and sewage treatment methods. Some of these factors are antagonistic and vary over time, therefore it is difficult to give a precise and reliable water demand value for the end of this century or for a longer time perspective.

\section{CONCLUSIONS}

This preliminary long-term predictive modelling carried out by the authors, however burdened with some uncertainty, revealed that the groundwater resources in aquifer recharged by rain infiltration in the study area at the end of the $21^{\text {st }}$ century may decrease due to climate change, compared to the reference period 1971-1990. The predicted amount of groundwater reserve, resulting from this modelling, depends importantly on the assumed forecasted climate model, based on particular ensembles of SRES with given RCM, and other adopted assumptions.

Simplifications in the proposed method of long-term variant predictive modelling of reserves of groundwater resources cause that the estimative variant models obtained in this preliminary study do not give grounds to take formal decisions and modifications to the existing water management plans and action programs in this field in the study area. However, the results of presented models, despite considerable differences and uncertainties depending on the adopted ensembles of SRES with given RCM and adopted assumptions to modelling, should help to promote protection of the quantity and quality of contemporary groundwater resources in aquifer recharged by rain infiltration in the study area and its vicinity.

After some modifications that are related, for example, to the adoption of some source data and assumptions, particularly regarding the amount of environmental flow in rivers and forecasted water demand in distant future, a similar approach could be a tool for this type of long-term predictive modelling of the impact of future climate warming on reserves of groundwater resources.

In further modelling of this type, it is also necessary to take models of future climate changes that are more accurate than SRES, i.e. models based on representative concentration pathways (RCPs) of greenhouse gases. Furthermore, more detailed water demand scenarios should be devised for the final decades of the 21st century (and for even longer time perspectives), as they provide the basis for more reliable projections of the effects of climate change on groundwater resources. For this purpose, an interdisciplinary approach, taking into account social and economic factors, should be implemented.

Acknowledgements. This research was financially supported by the AGH University of Science and Technology under grant No. 11.11.140.797. The authors wish to thank all those involved in the review of this paper, especially $\mathrm{Dr} P$. Herbich, for valuable remarks that significantly improved the value of this article and also Dr K. Leszczyński. This paper has been presented at the CAGG2019 Conference, 10-13 September 2019, Krakow, Poland.

\section{REFERENCES}

Acreman, M., 2016. Environmental flows - basics for novices. WIREs Water, 3: 622-628.

Aeschbach-Hertig, W., Gleeson, T., 2012. Regional strategies for the accelerating global problem of groundwater depletion. Nature Geoscience, 5: 853-861.

Ali, R., McFarlane, D., Varma, S., Dawes, W., Emelyanova, I., Hodgson, G., Charles, S., 2012. Potential climate change im- pacts on groundwater resources of south-western Australia. Journal of Hydrology, 475: 456-472.

Baruffi, F., Cisotto, A., Cimolino, A., Ferri, M., Monego, M., Norbiato, D., Cappelletto, M., Bisaglia, M., Pretner, A., Galli, A., Scarinci, A., Marsala, V., Panelli, C., Gualdi, S., Bucchignani, E., Torresan, S., Pasini, S., Critto, A., Marcomini, A., 2012. Climate change impact assessment on Veneto and Friuli 
plain groundwater. Part I: an integrated modeling approach for hazard scenario construction. Science of the Total Environment, 440: 154-166.

Brown, T.C., Foti, R., Ramirez, J.A., 2013. Projected freshwater withdrawals in the United States under a changing climate. Water Resources Research, 49: 1259-1276.

Christensen, O.B., Drews, M., Christensen, J.H., Dethloff, K., Ketelsen, K., Hebestadt, I., Rinke, A., 2007. The HIRHAM Regional Climate Model Version $5(\beta)$. Technical report 06-17. Danish Climate Centre - DMI, Copenhagen. Available online: https://www.dmi.dk/fileadmin/Rapporter/TR/tr06-17.pdf

Ciscar, J.C., Iglesias, A., Feyen, L., Goodess, C.M., Szabó, L., Christensen, O.B., Nicholls, R., Amelung, B., Watkiss, P., Bosello, F., Dankers, R., Garrote, L., Hunt, A., Horrocks, L., Moneo, M., Moreno, A., Pye, S., Quiroga, S., van Regemorter, D., Richards, J., Roson, R., Soria, A., 2009. Climate change impacts in Europe. Final report of the PESETA research project. EC Joint Research Centre (JRC), Scientific and Technical Research Series, EUR 24093 EN, European Communities, Luxembourg. Available online: http://publications.jrc.ec.europa.eu/repository/handle/JRC55391

Crosbie, R.S., Dawes, W.R., Charles, S.P., Mpelasoka, F.S., Aryal, S., Barron, O., Summerell, G.K., 2011. Differences in future recharge estimates due to GCMs, downscaling methods and hydrological models. Geophysical Research Letters, 38: L11406.

Döll, P., Jiménez-Cisneros, B., Oki, T., Arnell, N.W., Benito, G., Cogley, J.G., Jiang, T., Kundzewicz, Z.W., Mwakalila, S., Nishijima, A., 2015. Integrating risks of climate change into water management. Hydrological Sciences Journal, 60: 4-13.

Earman, S., Dettinger, M., 2011. Potential impacts of climate change on groundwater resources - a global review. Journal of Water and Climate Change, 2: 213-229.

Emam, A.R., Kappas, M., Hosseini, S.Z., 2015. Assessing the impact of climate change on water resources, crop production and land degradation in a semi-arid river basin. Hydrology Research, 46: 854-870.

Gorelick, S.M., Zheng, Ch., 2015. Global change and the groundwater management challenge. Water Resources Research, 51: 3031-3051.

Green, T.R., 2016. Linking climate change and groundwater. In: Integrated Groundwater Management: Concepts, Approaches and Challenges (eds. A.J. Jakeman, O. Barreteau, R.J. Hunt, J.-D. Rinaudo and A. Ross): 97-141. Springer Open.

Green, T.R., Taniguchi, M., Kooi, H., Gurdak, J.J., Allen, D.M., Hiscock, K.M., Treidel, H., Aureli, A., 2011. Beneath the surface of global change: impacts of climate change on groundwater (Review). Journal of Hydrology, 405: 532-560.

Grela, J., Biedroń, I., Boroń, A., Gasior, M., Grzebinoga, M., Krawczyk, D., Madej, P., Olszar, M., Piszczek, M., 2018. Wdrożenie metody szacowania przepływów środowiskowych w Polsce. Etap II (in Polish). MGGP, Kraków, Warszawa.

Hao, C.F., He, L.M., Niu, C.W., Jia, Y.W., 2016. A review of environmental flow assessment: methodologies and application in the Qianhe River. IOP Conference Series: Earth and Environmental Science, 39: 012067.

Herbich, P., Przytuła, E., 2012. Bilans wodnogospodarczy wód podziemnych z uwzglednieniem oddziaływań wodami powierzchniowymi w dorzeczu Wisły (in Polish). Informator Państwowej Służby Hydrogeologicznej. Polish Geological Institute - National Research Institute, Warsaw.

Herbich, P., Kapuściński, J., Nowicki, K., Rodzoch, A., 2013 Metodyka określania zasobów dyspozycyjnych wód podziemnych w obszarach bilansowych z uwzględnieniem potrzeb jednolitych bilansów wodnogospodarczych - poradnik metodyczny (in Polish). BORGIS, Warszawa.

Hiscock, K., Sparkes, R., Hodgson, A., 2012. Evaluation of future climate change impacts on European groundwater resources. In: Climate Change Effects on Groundwater Resources. A Global Synthesis of Findings and Recommendations (eds. $\mathrm{H}$. Treidel, J.L. Martin-Bordes and J.J. Gurdak). International As- sociation of Hydrogeologists, International Contributions to Hydrogeology, 27: 351-365.

Holman, I.P., Allen, D.M., Cuthbert, M.O., Goderniaux, P., 2012 Towards best practice for assessing the impacts of climate change on groundwater. Hydrogeology Journal, 20: 1-4.

IMGW, 2018. Baza danych hydrologicznych (in Polish). Institute of Meteorology and Water Management, Warszawa.

Jackson, C.R., Meister, R., Prudhomme, C., 2011. Modelling the effects of climate change and its uncertainty on UK Chalk groundwater resources from an ensemble of global climate model projections. Journal of Hydrology, 399: 12-28.

Jacob, D., Petersen, J., Eggert, B., Alias, A., Christensen, O.B., Bouwer, L.M., Braun, A., Colette, A., Déqué, M., Georgievski, G., Georgopoulou, E., Gobiet, A., Menut, L., Nikulin, G., Haensler, A., Hempelmann, N., Jones, C., Keuler, K., Kovats, S., Kröner, N., Kotlarski, S., Kriegsmann, A., Martin, E., van Meijgaard, E., Moseley, C., Pfeifer, S., Preuschmann, S., Radermacher, C., Radtke, K., Rechid, D., Rounsevell, M., Samuelsson, P., Somot, S., Soussana, J.-F., Teichmann, C., Valentini, R., Vautard, R., Weber, B., Yiou, P., 2014. EURO-CORDEX: new high-resolution climate change projections for European impact research. Regional Environmental Change, 14: 563-578.

Jaworska-Szulc, B., 2015. Impact of climate change on groundwater resources in a young glacial multi-aquifer system. Polish Journal of Environmental Studies, 24: 2447-2457.

Kille K., 1970. Das Verfahren MoMNQ, ein Beitrag zur Berechnung der mittleren langjährigen Grundwasserneubildung mit Hilfe der monatlichen Niedrigwasserabflusse. Zeitschrift der Deutschen Geologischen Gesellschaft - Band Sonderba, Hydrogeologie u. Hydrogeochemie: 89-95, Hannover.

Kristvik, E., Muthanna, T.M., Alfredsen, K., 2019. Assessment of future water availability under climate change, considering scenarios for population growth and ageing infrastructure. Journal of Water and Climate Change, 10: 1-10.

Leng, G., Tang, Q., Rayburg, S., 2015. Climate change impacts on meteorological, agricultural and hydrological droughts in China. Global and Planetary Change, 126: 23-34.

Liu, J., Cao, G., Zheng, Ch., 2011. Sustainability of groundwater resources in the North China Plain. In: Sustaining Groundwater Resources. A Critical Element in the Global Water Crisis (ed. J.A.A. Jones): 69-87. International Year of Planet Earth, Springer Science and Business Media B.V.

Lorenz, D.J., DeWeaver, E.T., Vimont, D.J., 2010. Evaporation change and global warming: the role of net radiation and relative humidity. Journal of Geophysical Research: Atmospheres, 115: D20118.

Madej, P., 2018. Analiza metody szacowania przepływów środowiskowych w Polsce i podstawy jej weryfikacji (in Polish). Proceedings of Conference „Wdrożenie metody szacowania przepływów środowiskowych w Polsce”, Warszawa.

Malekinezhad, H., Banadkooki, F.B., 2017. Modeling impacts of climate change and human activities on groundwater resources using MODFLOW. Journal of Water and Climate Change, 9: 156-177.

Meza, F.J., Vicuńa, S., Jelinek, M., Bustos, E., Bonelli, S., 2014 Assessing water demands and coverage sensitivity to climate change in the urban and rural sectors in central Chile. Journal of Water and Climate Change, 5: 192-203.

Miętus, M., Wibig, J., 2011. Projekt KLIMAT - wpływ zmian klimatu na środowisko, gospodarkę i społeczeństwo. Zadanie 1-Zmiany klimatu i ich wpływ na środowisko naturalne Polski oraz określenie ich skutków ekonomicznych (in Polish). Institute of Meteorology and Water Management, Warszawa-Gdynia-Kraków: http://klimat.imgw.pl/wp-content/uploads/2013/02/ Zadanie1 2011.pdf

Moss, R.H., Edmonds, J.A., Hibbard, K.A., Manning, M.R., Rose, S.K., Vuuren, D.P., Carter, T.R., Emori, S., Kainuma, M., Kram, T., Meehl, G.A., Mitchell, J.F.B., Nakicenovic, N., Riahi, K., Smith, S.J., Stouffer, R.J., Thomson, A.M., Weyant, J.P., Wilbanks, T.J., 2010. The next generation of scenarios for 
climate change research and assessment. Nature, 463: 747-756.

Nakićenović, N., Alcamo, J., Grubler, A., Riahi, K., Roehrl, R.A., Rogner, H.-H., Victor, N., 2000. Special Report on Emissions Scenarios (SRES). A Special Report of Working Group III of the Intergovernmental Panel on Climate Change. Intergovernmental Panel on Climate Change, Cambridge University Press, Cambridge. Available online: http://pure.iiasa.ac.at/6101

Ng, G.-H.C., McLaughlin, D., Entekhabi, D., Scanlon, B.R., 2010. Probabilistic analysis of the effects of climate change on groundwater recharge. Water Resources Research, 46: W07502.

Olichwer, T., Tarka, R., 2015. Impact of climate change on the groundwater run-off in south-west Poland. Open Geosciences, 7: 1-14.

Paczyński, B., Sadurski, A. eds., 2007. Hydrogeologia regionalna Polski, tom I - wody słodkie (in Polish). Polish Geological Institute, Warszawa.

Parasiewicz, P., Prus, P., Suska, K., Marcinkowski, P., 2018. "E=mc2" of environmental flows: a conceptual framework for establishing a fish-biological foundation for a regionally applicable environmental low-flow formula. Water, 10: 1501.

Pusłowska-Tyszewska, D., Tyszewski, S., 2018. Attempt at implementing the 2015 "Ecological Flow Assessment Method For Poland" in the Wieprza River catchment. Acta Scientiarum Polonorum, Formatio Circumiectus, 17: 181-193.

Riahi, K., Rao, S., Krey, V., Cho, C., Chirkov, V., Fischer, G., Kindermann, G., Nakicenovic, N., Rafaj, P., 2011, RCP 8.5 - a scenario of comparatively high greenhouse gas emissions. Climatic Change, 109: 33-57.

Staśko, S., Tarka, R., Olichwer, T., 2012. Groundwater recharge evaluation based on the infiltration method. In: Groundwater Quality Sustainability (eds. P. Maloszewski, S. Witczak and G. Malina). International Association of Hydrogeologists, Selected Papers, 17: 189-197.

Tarka, R., Olichwer, T., Staśko, S., 2017. Evaluation of groundwater recharge in Poland using the infiltration coefficient method. Geological Quarterly, 61 (2): 384-395.
Taylor, R.G., Scanlon, B., Döll, P., Rodell, M., Van Beek, R., Wada, Y., Longuevergene, L., Lablanc, M., Famiglietti, J.S., Edmunds, M., Konikow, L., Green, T.R., Chen, J., Taniguchi, M., Bierkens, M.F.P., Macdonald, A., Fan, Y., Maxwell, R.M., Yechieli, Y., Gurdak, J.J., Allen, D.M., Shamsudduha, M., Hiscick, K., Yeh, P.J.F., Holman, I., Treidel, H., 2012. Groundwater and climate change. Nature Climate Change, 3: 322-329.

Tharme, R.E., 2003. A global perspective on ecological flow assessment: emerging trends in the development and application of ecological flow methodologies for rivers. River Research and Applications, 19: 397-441.

Thomson, A.M., Calvin, K.V., Smith, S.J., Kyle, G.P., Volke, A., Patel, P., Delgado-Arias, S., Bond-Lamberty, B., Wise, M.A., Clarke, L.E., Edmonds, J.A., 2011. RCP4.5: a pathway for stabilization of radiative forcing by 2100 . Climatic Change, 109: 77-94.

Tillman, F.D., Gangopadhyay, S., Pruitt, T., 2016. Changes in groundwater recharge under projected climate in the upper Colorado River basin. Geophysical Research Letters, 43: 6968-6974.

Vetter, T., Reinhardt, J., Floerke, M., van Griensven, A., Hattermann, F., Huang, S., Koch, H., Pechlivanidis, J., Ploetner, S., Seidou, O., Su, B., Vervoort, R.W., Krysanova, V., 2017. Evaluation of sources of uncertainty in projected hydrological changes under climate change in 12 large-scale river basins. Climatic Change, 141: 419-433.

Wada, Y., van Beek, L.P.H., van Kempen, Ch.M., Reckman, J.W.T.M., Vasak, S., Bierkens, M.F.P., 2010. Global depletion of groundwater resources. Geophysical Research Letters, 37: L20402.

Winkler, J.A., Guentchev, G.S., Perdinan, Tan, P.-N., Zhong, S., Liszewska, M., Abraham, Z., Niedźwiedź, T., Ustrnul, Z., 2011. Climate scenario development and applications for local/regional climate change impact assessments: an overview for the non-climate scientist, Part I: scenario development using downscaling methods. Geography Compass, 5/6: 275-300. 